\title{
Long Term Effects of Human Induced Shoreline Changes: Veracruz Metropolitan Zone an Example of Port and Tourism Development in the Tropics
}

\author{
Veronica VR1 ${ }^{1}$, David SM2* and Leonardo DOL ${ }^{2}$ \\ ${ }^{1}$ Instituto Tecnologico de Boca del Rio. Posgrado en Ecologia y Pesquerias, Universidad \\ Veracruzana, Mexico. \\ ${ }^{2}$ Instituto de Ciencias Marinas y Pesquerias, Universidad Veracruzana, Mexico
}

Research Article

Volume 2 Issue 4

Received Date: June 20, 2018

Published Date: June 28, 2018

*Corresponding author: David Salas-Monreal, Instituto de Ciencias Marinas y Pesquerías, Universidad Veracruzana, Boca del Río, Veracruz, Mexico, Email: México davsalas@uv.mx

\section{Abstract}

Human development in coastal zones is closely related with coastline modification due to coastal defense structures (CDS) and landfills. To contribute to a better understanding of long-term effects of CDS over three sensitive coastal natural systems: coral reefs, river inlets and sandy beaches in tropical areas, we used the Veracruz Bay (Mexico) as a case study, since it has all of the above mentioned environments and its development has included the construction of all types of CDS (breakwaters, groynes and jetties). A model of evolution was developed based on digitized coastlines from mosaicked historical aerial photographs. Historical CDS construction, coastline overlapping analysis to assess erosionaccretion and a sediment transport modelling resulted in the identification of long-term changes in sedimentation rates of up to $5 \mathrm{~cm}^{3} \mathrm{yr}^{-1}$, which affects shallow coral reefs within a Marine Protected Area causing sub-lethal stress. We also identified accretion areas within port facilities which increase port maintenance costs. Accelerated erosion associated to CDS located in natural erosion areas was identified on touristic sandy beaches and deviations of the desired effect of jetties constructed in the Jamapa River inlet. All information reported here coincide with studies around the world on the effects of CDS but helps to reconstruct a case study that could be useful to understand the magnitude of long term impacts on coastal sensitive systems.

Keywords: Erosion; Coral Reef; Long-Term Impacts; Costal Defense; Beach Erosion; Veracruz Reef System (VRS)

\section{Introduction}

Human development in coastal zones is closely related with coastline modification. Coastal defense structures (CDS) and landfills aim to modify coastline or preserve it [1], frequently with no previous studies of the area. This usually results in the acceleration of natural coastal erosion. CDS such as breakwaters, groynes and jetties interfere with littoral drift, resulting in sedimentation budget modification and shoreline impacts [1]. Land reclamation, with landfills of diverse materials to gain land, to meet the growing economic and societal demands 


\section{International Journal of Oceanography \& Aquaculture}

in coastal zones worldwide modifies coastal geomorphology and affect sensitive habitats. They also lead to construct more CDS to preserve reclaimed land [2]. The impacts of CDS and landfills occur in long-term time scales (decades) observed at spatial local-scale [3,4]. Studies report erosion, change in coastal energy, alteration of sedimentary budgets and ecological impacts to coastal environments. These impacts produce habitat replacement, fragmentation, changes in habitat composition, stress or sub-lethal and lethal effects [5-7]. The stretch of coast between the Port of Veracruz and the Jamapa River inlet in Veracruz Bay (western Gulf of Mexico) has been modified historically with CDS (Figure 1). The Veracruz Metropolitan Zone (VMZ) is one of the most important coastal cities in the Mexican Gulf of Mexico. It has been the principal western terminus of trade since the colonial period $[8,9]$. Most CDS in this area were located without previous studies, as it is the case of most countries worldwide [10]. The construction of such structures may sometimes require economical budgets that exceed the economic and ecological benefits of its construction. Further, the Jamapa River inlet has two jetties of 0.24 and $0.45 \mathrm{~km}$, respectively, constructed to protect the river mouth from sedimentation. Those structures are common in most countries; however, in most cities around the world they become harmful for the adjacent land. The VMZ is also a touristic destiny, which has led to the construction of groynes in order to avoid sand beach erosion. As in many other places, they enhance the erosion of adjacent beaches [10]. Thus, the VMZ has almost all types of CDS, therefore it has all the major problems related with development pressures near sensitive environments [4]. Among these environments, shallow coral reefs are affected by sedimentation due to natural and anthropogenic effects. Sedimentation rates of over $25 \mathrm{mg} \mathrm{cm}^{-2} \mathrm{~d}^{-1}$ cause severe stress resulting in coral mortality [11]. Some studies reported [7], that around the world, most coral species experience stress with mortality at rates of over $100 \mathrm{mg} \mathrm{l}^{-1}$ day $^{-1}$. CDS may also generate erosion of sandy beaches, which in some cases are refilled with added sand from other areas. The cost of added sand from a sand bank may reach up to $\$ 18.75$ usd per cubic meter and from dredging, up to $\$ 22.37$ USD per cubic meter [12]. Finally, the construction of CDS with no previous studies may increase the sedimentation rate in areas such as ports and marinas; in those places the dredging price in the world has been estimated of up to 21 usd per cubic meter [13].

The aim of this study is to contribute to a better understanding of the long-term effects of human induced coastline modifications, through a model of evolution, based on aerial historical photographs, for a complex stretch of coastline, where development pressures increase near sensitive coastal ecosystems. This case study shows the advantages and disadvantages of coastal protection structures over natural systems such as sand beaches, coral reefs and river inlets.

The city of Veracruz (Figure 1) was established around a commercial port constructed in 1600 [8]. Since 1940 CDS and landfills have been constructed to attend port development pressures.

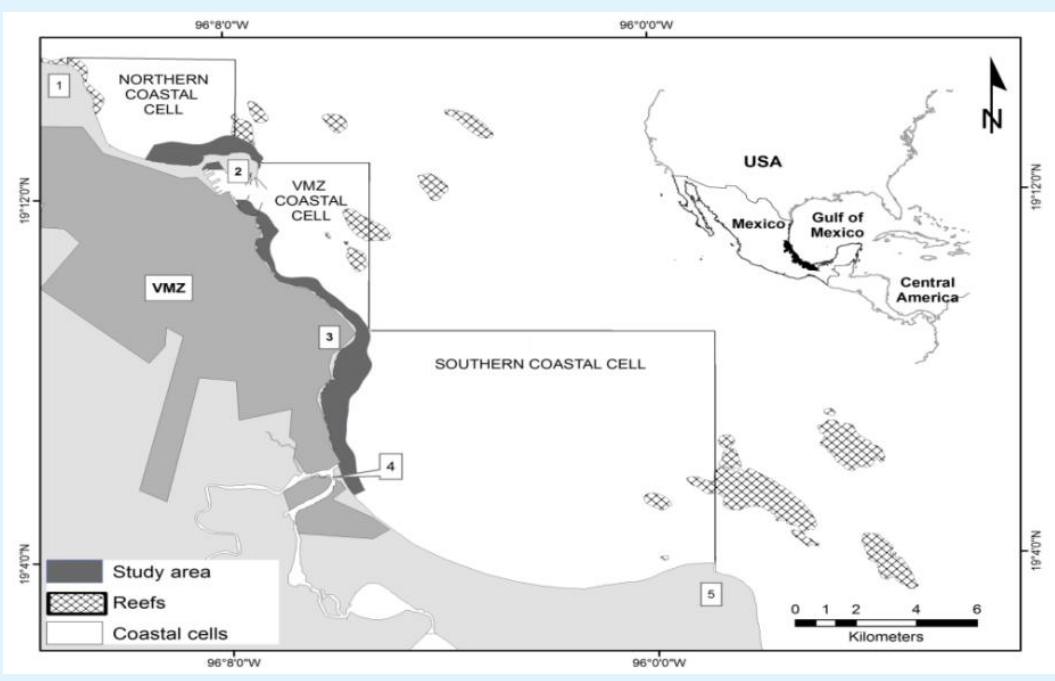

Figure 1: Study Area within Veracruz Bay and the three identified coastal cells near to the Veracruz Metropolitan Zone (VMZ). The numbers represents; 1. Punta Gorda headland; 2. Port of Veracruz; 3. Punta Mocambo headland; 4. Jamapa River inlet; and 5 Punta Anton Lizardo headland. 


\section{International Journal of Oceanography \& Aquaculture}

It is the most important port in the eastern Mexican shores, which neighbors with a Marin Protected Area (MPA) with shallow and deep coral reef structures $[4,19]$. The site is influenced by a large-scale current pattern [14] from the Campeche Bay [15] which influences the area, and is locally modified by the presence of coral reefs, islands and local wind stress [3,14]. It is also characterized by the presence of diurnal tides [16]. Coastal studies in Veracruz Bay have focused on coastal orientation patterns [17], river mouth [18], port effect over ecological systems [4] and to economic implications generated by coastal infrastructures [17]. However, resent studies supported by the Port of Veracruz have provided more information than in the last decade; this information is available for scientific purposes [19]. The aim of this study is to elucidate the effects of CDS (breakwaters, groynes and jetties) on tropical coastal areas near sensitive environments such as coral reefs, river inlets and touristic sandy beaches.

\section{Material and Methods}

A $25 \mathrm{~km}$ coast line stretch of VMZ (Figure 1) was digitized from vertical aerial photographs. It was georeferenced using Ground Control Points (GCP's), computer rectified and mosaicked together [20] using ARC GIS 9.3. Three sets of photographs from 1946, 1975 (ICA foundation) and 2007 (INEGI government agency) were used to digitize the coastline. Digitization was made for each year by photo-interpretation using ARC GIS 9.3 and the Mean Water Line (MWL) coastline concept $[21,22]$. The error related to the photographs distortion $[23,24]$ has been solved by comparison of ortophotos with the base map and using the mean root square error, which was calculated using the GCPs data of each photogram.

Coastal cells were identified in the study area, defined as coastal compartments containing the complete cycle of erosion, deposition, sediment sources and sinks and the transport paths involved [25] and identified by the presence of headlands which compartmentalize the shoreline into sediment cells, semicircular in shape [26].

Digitized coastlines of different years were overlapped and accretion-erosion areas were identified in each cell creating polygonal layers. These polygons were used to calculate coastline changes per period, using ARCGIS 9.3. Accretion areas were classified as landfills and accretion areas based on the mosaic analysis and knowledge of the study area. Sensitive coastal systems such as reefs, sandy beach and river inlets were identified in each cell and were historically analyzed reconstructing the story of CDS structure.

In addition, for a thorough understanding of the sedimentation impact to shallow reefs of the MPA near the Port of Veracruz, the Regional Ocean Model System (ROMS) was used to simulate sediment transport near the coast. The three-dimensional primitive equations ocean model uses $\sigma$ coordinates to increase the vertical resolution in the coastal areas. The model simulates the sediment transport using the bathymetry reported by Salas-Monreal, et al. [3] and the two years of moored currents, temperature, and sea levels obtained from SalasPerez, et al. [14]. The bottom stress was assumed to be a quadratic function of the bottom velocity with a drag coefficient of $2.3 \times 10^{-3}$ [27]. The tidal amplitude and phase were obtained from previous oceanographic studies of the area [14]. The stability of the model was analyzed using the potential and kinetic energy. Once differences in energies from successive iterations were on the order of $10^{-3}$ or lower, the model was considered to be stable. The yearly average sedimentation rate obtained from the model was used to describe the effects on sensitive coastal systems, mainly coral reef areas.

\section{Results}

Interpretations and models are based on aerial photographic mosaics which have a mosaic mean error of $1.6 \mathrm{~m}$ for the 1976 mosaic and $2.2 \mathrm{~m}$ for the 1946 mosaic, using the 2017 mosaic as a reference. Three coastal cells were identified (figure 1): a) A northern cell, limited by a natural headland known as Punta Gorda (located north from the study area) and the Port of Veracruz (artificial headland), which neighbors La Gallega reef (figure 2); b) The Veracruz Metropolitan Zone (VMZ) cell, from the Port of Veracruz to Punta Mocambo headland (figure 3); and c) the southern cell, from Punta Mocambo headland to Punta Anton Lizardo (figure 4). Three sensitive coastal systems (shallow coral reefs, sandy beaches and a river inlet) were detected within the three coastal cells: a) Coral reefs located in the first cell, b) Sandy beaches located from Punta Mocambo in the first cell to the third cell, and c) the Jamapa river inlet located in the third cell which is a major urban and tourism development area known as "Riviera Veracruzana". 


\section{International Journal of Oceanography \& Aquaculture}
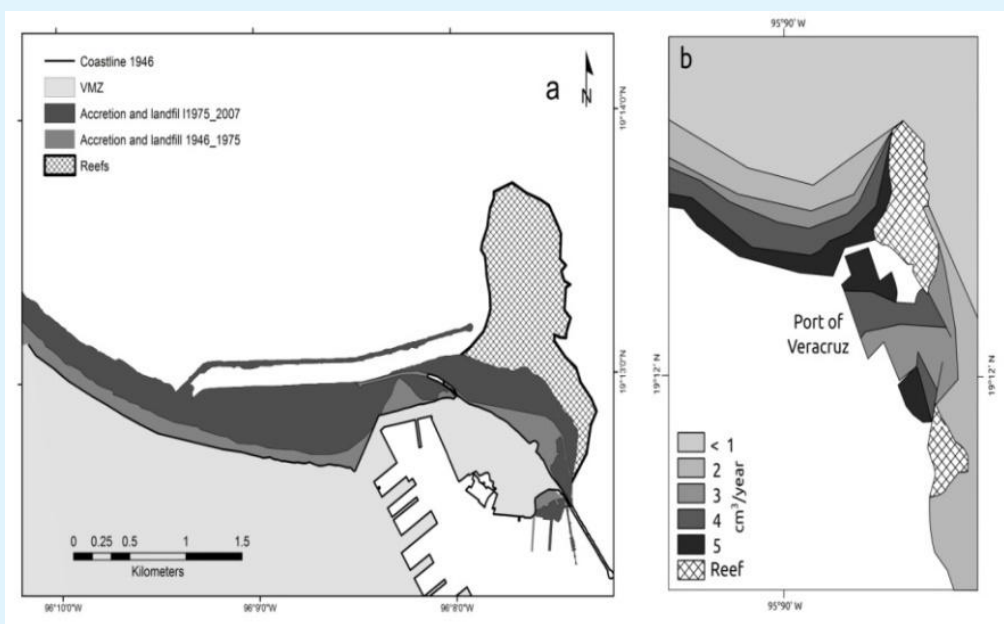

Figure 2: a) Long-term coastline changes associated to CDS in the two periods: 1946-1975, 1975-2007; b) ROMS sedimentation model in the outer and inner part of the port.

\section{Port of Veracruz Area}

In the 1946-1975 period landfills over shallow reef areas next to the Port of Veracruz and the construction of a northern breakwater were made to retain sand. In the 1975-2007 period more landfills over shallow reef areas and the reconstruction of a larger breakwater up to $3 \mathrm{~km}$ were made. Coastline overlapping analysis showed that 68.35 ha $\left(0.6835 \mathrm{~km}^{2}\right)$ were gained in the 1946-1975 period around the port facilities of Veracruz (Figure 2a): 32.60 ha were gained from landfills over shallow coral reefs for port expansion and 35.75 ha were gained by littoral transport blockage (Table 1).

\begin{tabular}{|c|c|c|c|c|c|c|}
\hline & \multicolumn{2}{|c|}{ Port } & \multicolumn{2}{c|}{ Mocambo } & \multicolumn{2}{c|}{ Jamapa Inlet } \\
\hline Period & Erosion & Landgain & Erosion & Landgain & Erosion & Landgain \\
\hline $1946-1975$ & 0 & 68.35 & 10.75 & 8.5 & 21.72 & 9.55 \\
\hline $1975-2007$ & 0 & 168.55 & 4.51 & 13.74 & 8.57 & 32.22 \\
\hline
\end{tabular}

Table 1: Total landgain and erosion per period. Expressed in hectares (ha).

La Gallega Reef a natural headland and the port which works as an artificial headland, generates sediment accumulation in the northern part of the Port. No erosion was detected in this period. CDS constructed in this period include 4 groynes associated to beach and landfills for urban expansion and 2 breakwaters at the port entrance.

In the 1975-2007 period a $3 \mathrm{~km}$ long breakwater was constructed causing accretion in the north. Up to 230 meters of beach were gained in its narrower part and up to 477 meters in its widest part. No erosion was detected in this period. 168.55 ha $\left(1.6855 \mathrm{~km}^{2}\right)$ of land gain were observed. 167.54 ha were gained through landfill and 1.01 ha were gained in the accumulation zone in the north (figure 2a). The sedimentation rate calculated by ROMS was of 4 to $5 \mathrm{~cm}^{3} \mathrm{yr}^{-1}$ for the western part of La Gallega reef from 1946 to 1975 (figure 2b), implying that this reef should be naturally sand cover in the future. It may also be assumed that the breakwater constructed for port expansion in the following period (1975-2007) retarded sedimentation rate to reach the shallow coral reef area of La Gallega, while sediments may accumulate near the base of the breakwater. However in the midterm (years to decade) sediment will reach the reef area owing to the natural sedimentation rate. The sedimentation model showed sedimentation rates inside the Port of Veracruz facilities of 3 to $5 \mathrm{~cm}^{3} \mathrm{yr}^{-1}$ (figure 2b). The present CDS retains sediments mostly outside the port facilities, however during easterly wind conditions the sediments may get into the port facilities [3] increasing maintenance costs.

\section{Punta Mocambo Headland.}

In the 1945-1975 period no CDS were constructed (Figure 3). In the 1975-2007 five groynes were constructed in the northern side of the headland, which is bordered by sandy beach and two more were constructed 


\section{International Journal of Oceanography \& Aquaculture}

in the southern part of the headland. Coastline overlapping analysis for the 1946-1975 period at Punta Mocambo headland, showed a mobile dune field with long narrow sandy beaches and no CDS structures. This area showed a natural erosion of $8.5 \mathrm{Ha}$ and accretion areas of 10.75 ha (figure 3 ).

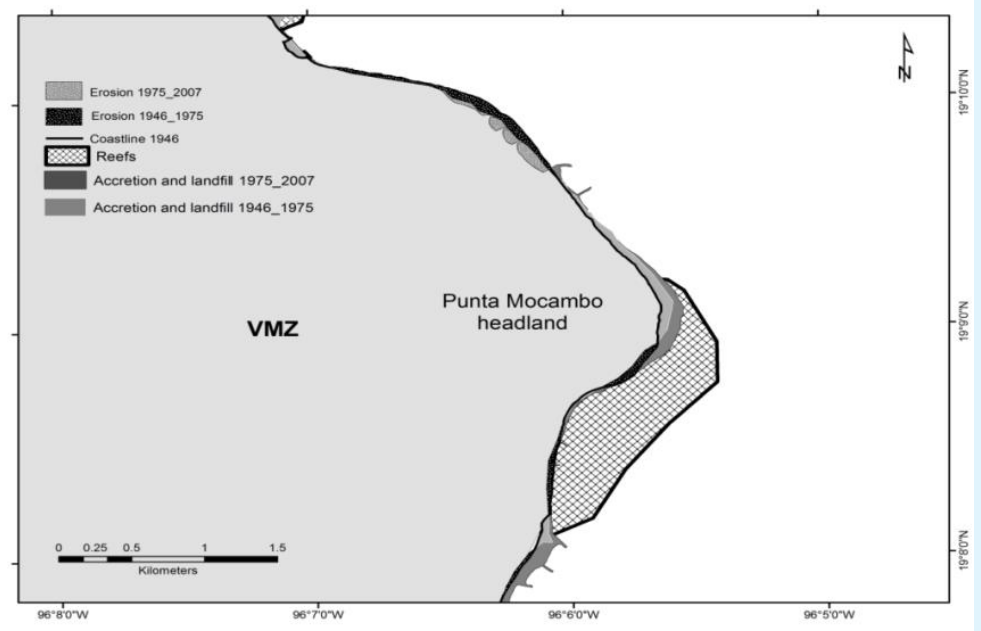

Figure 3: Punta Mocambo long-term changes associated to CDS. Erosion and accretion areas in the 1946-1975 and the 1975-2007 periods, including the construction of 7 groynes.

In the $1975-2007$ period, 13.74 ha $\left(0.1374 \mathrm{~km}^{2}\right)$ of beach were gained (figure 3$)$ and only 4.51 ha $(0.0451$ $\mathrm{km} 2$ ) were lost. Erosion occurred in the beach area located at the northern end of the cell, in the natural erosion area detected in the previous period. The groynes accelerated the erosion of the neighboring southern beach stretch; however, they retained sand erosion inside the two groynes as expected. The erosion area located in front of the fringing reef, observed during the period of 1945 to
1975 was not detected during the period of 1975 to 2007 (Figure 3).

\section{Jamapa River Inlet}

In the 1946-1975 period a 140 meter jetty in the northern shore of the inlet and seven groynes were constructed in a $3.5 \mathrm{~km}$ stretch of coastline with sandy beach (Figure 4).

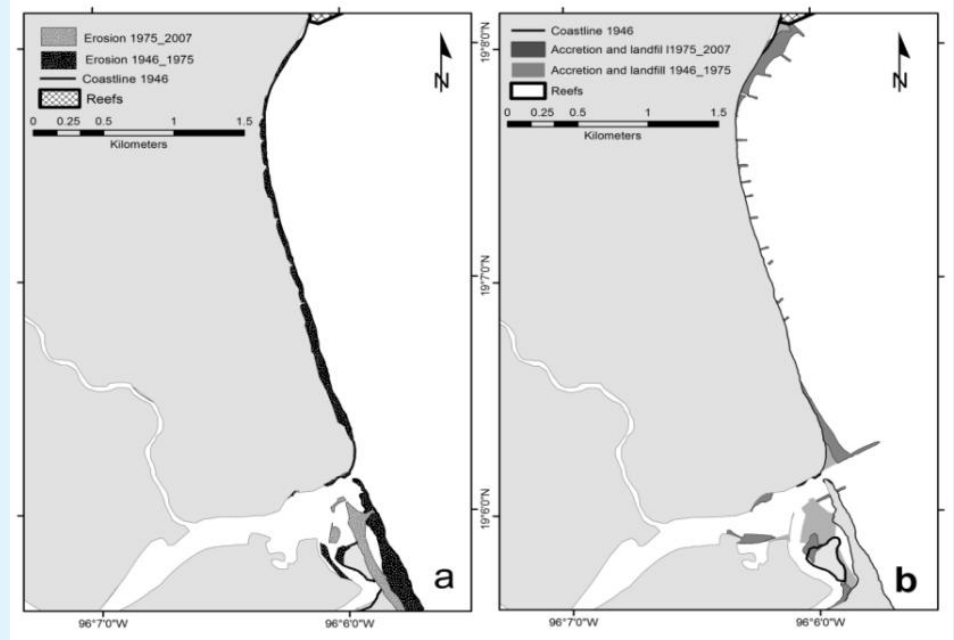

Figure 4: Long term coastline changes associated to CDS near Jamapa Inlet: a) erosion areas in 1946-1975 and 19752007 periods; b) Accretion areas in 1946-1975 and 1975-2007 periods, including the construction of groynes and jetties. 


\section{International Journal of Oceanography \& Aquaculture}

Coastline overlapping analysis showed a total of 21.72 ha $\left(0.2172 \mathrm{~km}^{2}\right)$ eroded. The Jamapa inlet sandbar was lost in this period. In the 1975-2007 period seven additional groynes were constructed to stop erosion, the northern jetty was extended to $450 \mathrm{~m}$ and one more jetty was constructed in the southern shore with a $240 \mathrm{~m}$ length. Up to 8.57 ha were lost along the stretch of coastline and a total of 32.22 ha were gained in the $3.5 \mathrm{~km}$ stretch of coastline with sand beach mentioned before (Figure 3b).

\section{Discussion}

CDS are constructed with a particular intended purpose: To hold the coast line in its place; to reclaim land and protect it; to reduce wave and current energy to favor maritime transport or to prevent sedimentation or erosion (Table 2).

\begin{tabular}{|c|c|c|c|c|c|}
\hline Environment & CDS & Intended Effect & Observed effect & Reported Effect & Author \\
\hline \multirow{4}{*}{$\begin{array}{l}\text { Shallow } \\
\text { coral reef }\end{array}$} & \multirow[b]{2}{*}{ Breakwater } & \multirow{2}{*}{$\begin{array}{l}\text { Wave energy } \\
\text { reduction for } \\
\text { navigation } \\
\text { purposes }\end{array}$} & Beach accretion & Downdrift shoreline erosion & \multirow[b]{2}{*}{$\begin{array}{l}\text { Valadez-Rocha } \\
\text { and Ortiz } \\
\text { Lozano } 2013\end{array}$} \\
\hline & & & $\begin{array}{c}\text { Increased sedimentation } \\
\text { in coral reef areas }\end{array}$ & Reef Burial. & \\
\hline & \multirow{2}{*}{ Landfills } & $\begin{array}{l}\text { Modify coastal } \\
\text { geomorphology }\end{array}$ & \multirow{2}{*}{$\begin{array}{l}\text { Habitat loss; increased } \\
\text { sedimentation of lethal } \\
\text { and sub-lethal level }\end{array}$} & \multirow{2}{*}{$\begin{array}{c}\text { Habitat loss, ecological } \\
\text { damage to intertidal } \\
\text { communities and shallow } \\
\text { marine ecosystems }\end{array}$} & \multirow{2}{*}{$\begin{array}{l}\text { Erftermeijer et } \\
\text { al. } 2012\end{array}$} \\
\hline & & $\begin{array}{l}\text { (Chou and Tunn } \\
\text { 2005) }\end{array}$ & & & \\
\hline \multirow[t]{2}{*}{ Beach } & \multirow[t]{2}{*}{ Groynes } & \multirow[t]{2}{*}{ Hold the coast line } & \begin{tabular}{|c|} 
a. Increased erosion \\
when located in erosion \\
areas. \\
\end{tabular} & \multirow{2}{*}{$\begin{array}{c}\text { Erosion and accretion of } \\
\text { adjacent shorelines on each } \\
\text { side. }\end{array}$} & \\
\hline & & & \begin{tabular}{|c|}
$\begin{array}{c}\text { b. Preserve the coast } \\
\text { line }\end{array}$ \\
\end{tabular} & & $\begin{array}{l}\text { Norsdtrom } \\
2000 \\
\end{array}$ \\
\hline \multirow[b]{2}{*}{ Inlet } & \multirow[b]{2}{*}{ Jetties } & \multirow{2}{*}{$\begin{array}{l}\text { Prevent inlet } \\
\text { sedimentation }\end{array}$} & $\begin{array}{c}\text { Sand accretion on one } \\
\text { side. }\end{array}$ & \multirow{2}{*}{$\begin{array}{c}\text { Affect sediment transport } \\
\text { Shoreline erosion accelerated } \\
\text { downcoast. }\end{array}$} & \multirow{2}{*}{$\begin{array}{l}\text { Houston and } \\
\text { Dean } 2016\end{array}$} \\
\hline & & & $\begin{array}{c}\text { Downdrift severe } \\
\text { erosion associated to } \\
\text { jetty length }\end{array}$ & & \\
\hline
\end{tabular}

Table 2: List of the sensitive system in VMZ case, the intended purpose of each type of CDS and the long term effects observed; it also lists the reported effects in other parts of the world.

From this analysis it was clear that the long term effect of the construction of CDS in the VMZ resulted in the desired effects only in two cases (four groynes located in accretion areas and a jetty located in the northern part of the Jamapa River inlet), without negative effects. In the other cases, long-term effects were contrary to desired for the adjacent beach areas. This effect is similar worldwide.

Ports in tropical areas around the world face pressures to increase handling capacity [9], this has led to projects based on studies which tend to prioritize immediate effects [4]. The Veracruz Port case shows that ports when constructed in an accretion area, have high economic and ecological costs. Based on these results it could be stated that port facilities should preferentially be constructed in erosive areas (Table 1) in order to minimize dredging costs (e.g. cell 1 for the case of the VMZ); when ports are built in accretion areas the dredged cost should be considered in the annual maintenance budget that will increase the operational cost.
A point to highlight is the sedimentation rate calculated here (4 to $5 \mathrm{~cm}^{3} \mathrm{yr}^{-1}$ or $35 \mathrm{mg} \mathrm{l}^{-1}$ day $^{-1}$ ) in the western part of the breakwater, that will eventually reach the western part of La Gallega Reef, even when the constructed breakwater retard its sedimentation budget. It is a high sedimentation rate based on the sedimentation rates reported by Eftermeijer, et al. [7] as the cause of sublethal and lethal effects to most coral species. Also the sedimentation rate obtained inside the port facilities show areas that will require more maintenance dredging than others, which will periodically contribute to increase the sedimentation rate of the surrounding waters during dredging [7], this effect should benefit the touristic surrounding beaches, but may affect neighbors coral reef areas.

Beach tourism is one of the principal sources of income in most tropical countries. Sandy beaches are assets to preserve, but historically CDS have been constructed without previous studies. The observed long 


\section{International Journal of Oceanography \& Aquaculture}

term impacts in the VMZ are similar to those observed in beach areas in most coastal areas of America, Africa, Oceania, Asia and Europe [10]. Beach management decisions including the construction of CDS or beach nourishment are reactive, not planned. Up to 2007, beaches in Punta Mocambo were refilled with sand every week, without knowledge of sediment dynamics, implying an annual cost of up to \$26 USD per cubic meter, including the dispersal of sand [12]. The erosion problem caused by CDS with erroneous location and the increased erosion rates due to current dynamics [3] becomes an economic problem for tourism investors (hotels and apartments) located in the front beach.

The Inlet case in the VMZ, which is a natural erosion area, shows how constructing CDS without knowledge on local sediment dynamics (northern jetty) led to the desired effect for a brief period, but then, increasing the length of the jetty and constructing one more jetty (southern jetty) accelerated the erosion rate, which in the long term eroded the southern sand bar, narrowing the beach. In the future, erosion will menace touristic and urban infrastructure toward the southern area of this jetty. This case is found in most river inlets around the world [28,29].

The main issue is that there is enormous pressure to accelerate coastal development in the VMZ. This, along with CDS projects based on previous shallow studies or sometimes without them have damaging impacts on sensitive environments and leads to get results which are far, or even contrary from desired. CDS construction should be decided regarding their economic and ecological feasibility and based on thorough oceanographic and sedimentation studies, such as the new released dataset by the Port of Veracruz General Administration, which has already lead to scientific studies within the VMZ [19].

\section{Conclusion}

Three sensitive coastal environments in Veracruz Marine Zone (VMZ) have been affected by long-term effects, related with the construction of CDS without previous studies (shallow coral reefs, river inlet and sand beaches). Breakwaters and Jetties are the principal CDS used to modify the shoreline for port facilities expansion and touristic beaches near river mouths; along with landfills without considering regional sediment dynamics, particularly in natural erosion areas may accelerate erosion. Such as for the case of the southern jetty of the Jamapa River inlet, which accelerate the erosion rate of the southern Jamapa River area. Port facilities should be built in erosion areas in order to avoid excessive maintenance costs. Finally, local knowledge and local studies should be made for CDS construction projects to achieve the desired effects.

\section{Acknowledgement}

The Mexican Consejo Nacional de Ciencia y Tecnología (CONACYT) provided a doctoral fellowship (161812) to the first author. This research was partially supported by the projects : CONACyT/89526, CONACyT/78773 and 327202010176 DGI-ICMP-UV "Influencia Histórica de la Ciudad y Puerto de Veracruz sobre el Sistema Arrecifal Veracruzano"; and by the "Red para el Analisis y Sintesis de la Zona Costera Veracruzana, Golfo de Mexico (RASZCOV)" through project "Bases para el Analisis y Sintesis de los Sistemas Costeros de Veracruz".

\section{References}

1. Cisin-Sain B, Belfiore S (2005) Linking marine protected areas to integrated coastal and ocean management: a review of theory and practice. Ocean Coast Manage 48(11): 847-868.

2. (2010) PIANC Dredging and port construction around coral reefs. Report 108. The World Association for Waterborne Transport Infrastructure. UNEP 94.

3. Salas-Monreal D, Salas-de-Leon DA, Monreal-Gomez NA, Riverón-Enzástiga ML (2009) Current rectification in a tropical coral reef system. Coral Reefs 28: 871-879.

4. Valadez RV, Ortiz LL (2013) Effects of expansion of port facilities on the surface area of shallow coral reefs: Historical Coastline changes in Veracruz, Mexico. Environ Manage 52(1): 250-260.

5. Maharaj RJ (2001) Monitoring and control of coral reef dredging: environmental and engineering implications in Pacific SIDS. In: SOPAC Miscellaneous Report 404: 16.

6. Chou LM, Tunn KPP (2005) Status of coral reefs in Southeast Asian countries: Singapore. In: Status of Coral Reefs in East Asian Seas Region: 2004. Japan: Ministry of the Environment 53-69.

7. Erftemeijer PLA, Riegl B, Hoeksema BW, Todd PA (2012) Environmental impacts of dredging and other sediment disturbances on corals: A review. Mar Pollut Bull 64(9): 1737-1765. 


\section{International Journal of Oceanography \& Aquaculture}

8. Smith RS (1943) Shipping in the Port of Veracruz, 1790-1821. The Hispanic American Historical Review 23(1): 5-20.

9. Wilmsmeier GJ, Monios J, Rodrigue P (2015) Drivers for outside-in port hinterland integration in Latin America: The case of Veracruz, Mexico. Research in Transportation Business and Management 14: 34-43.

10. Semeoshenkova V, Newton A (2015) Overview of erosion and beach quality issues in three Southern European countries: Portugal, Spain and Italy. Ocean Coast Manage 118: 12-21.

11. Schafer Nelson DF, McManus J, Richmond RH, King Jr DB, Gailani JZ (2016) Predicting dredging associated effects to coral reefs in Apra Harbor-Guam- Part 2: Potential coral effects. J Environ Manage 168: 111122.

12. Hippe A, Becker A, Fischer M, Schwegler B (2015) Estimation of cost required to elevate US ports in response to Climate Change. A thought exercise for climate critical resources. CIFE Working Paper \#WP138. Stanford University 28.

13. (2015) GAO US Government Accountability Office. A report to the Chairman, Subcommittee on Transportation and Infrastructure, Committee on environment and Public Works, US Senate (GAO-15810) 33.

14. Salas-Pérez JJ, Salas-Monreal D, Monreal-Gómez MA, Riverón-Enzástiga ML, Llasat C (2012) Seasonal absolute acoustic intensity, atmospheric forcing and currents in a tropical coral reef system. Estuar Coast Shelf S 100: 102-112.

15. Monreal-Gómez MA, Salas-de-León DA, VelascoMendoza H (2004) La hidrodinámica del Golfo de México: diagnóstico ambiental del Golfo de México. In: Caso M, Pisanty I, Ezcurra E (Eds.), Instituto Nacional de Ecología, SEMARNAT, México, pp: 47-68.

16. Salas-Pérez JJ, Granados-Barba A (2008) Oceanographic characterization of the Veracruz Reefs System. Atmosfera 21(3).

17. Heinecke D, Volbeda E, de Weerdt B, De Wit F (2014) Project Veracruz: An assessment of the eroding beach south of Veracruz. TU Delft, Department of Environmental Engineering.

18. Chacon-Gomez IC, Salas-Monreal D, RiveronEnzastiga ML (2013) Current pattern and coral larval dispersion in a tropical coral reef system. Cont Shelf Res 68: 23-32.

19. Ortiz-Lozano L, Colmenares-Campos C, GutiérrezVelázquez A (2018) Submerged Coral Reefs in the Veracruz Reef System, Mexico, and its implications for marine protected area management. Ocean \& Coastal Management 158: 11-23.

20. Coyne MA, Fletcher CH, Richmond BM (1999) Mapping coastal erosion hazard areas in Hawaii: observations and errors. J Coast Res SI 28: 171-184.

21. Boak EH, Turner IL (2005) Shoreline definition and detection: a review. J Coast Res 21(4): 688-703.

22. Leatherman SP (2003) Shoreline change mapping and management along the US coast. J Coast Res SI 38: 513.

23. Anders FJ, Byrnes MR (1991) Accuracy of shoreline change rates as determined from maps and aerial photographs. Shore and Beach 59(1): 17-25.

24. Moore AM, Arango HG, Di Lorenzo E, Cornuelle BD, Miller AJ, et al. (2004) A comprehensive ocean prediction and analysis system based on the tangent linear and adjoint of a regional ocean model. Ocean Model 7(1-2): 227-258.

25. (2004) EUROSION A Guide to Coastal Erosion Management Practices in Europe. Contract B4e3301/2001/329175/MAR/B3. Prepared by Rijkswaterstaat/RIKZ. The Haque, The Netherlands.

26. Van Rijn LC (2011) Coastal erosion and control. Ocean Coast Manage 54(12): 867-887.

27. Monreal-Gomez MA, Salas-de-León DA (1990) Simulación de la circulación en la Bahía de Campeche. Geofís Int 29: 101-111.

28. Frihy OE (2001) The necessity of environmental impact assessment (EIA) in implementing coastal projects: lessons learned from the Egyptian Mediterranean Coast. Ocean Coast Manage 44(7-8): 489-516.

29. Houston JR, Dean RG (2016) Erosional impacts of modified inlets, beach encroachment, and beach nourishment on the east coast of Florida. J Coast Res 32(2): 227-240. 


\section{International Journal of Oceanography \& Aquaculture}

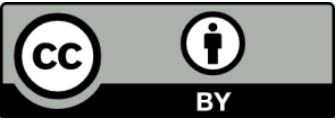

